\title{
Részvételi akciókutatással a társadalmi kirekesztés ellen: egy szegedi példa tanulságai
}

\author{
Participatory action research and social integration: \\ conclusions of a case study in Szeged
}

\author{
MÁLOVICS GYÖRGY, MIHÓK BARBARA, PATAKI GYÖRGY, \\ SZENTISTVÁNYI ISTVÁN, ROBOZ ÁGNES, BALÁZS BÁLINT, \\ NYAKAS SZABOLCS
}

MÁLOVICS György: Akciókutatók a Fenntarthatóságért Egyesület (AKUT); egyetemi docens, Szegedi Tudományegyetem, Gazdaságtudományi Kar, Szeged; malovics.gyorgy@eco.u-szeged.hu MIHÓK Barbara: Akciókutatók a Fenntarthatóságért Egyesület (AKUT), Szeged; akutegyesulet@gmail.com

PATAKI György: Budapesti Corvinus Egyetem, Környezetgazdaságtani és Technológiai Tanszék, Budapest; Környezeti Társadalomkutatók (ESSRG), Gödöllő; Akciókutatók a Fenntarthatóságért Egyesület (AKUT), Szeged; gyorgy.pataki@corvinus.hu

SZENTISTVÁNYI István: Akciókutatók a Fenntarthatóságért Egyesület (AKUT), Szeged; iszentistvanyi@gmail.com

ROBOZ Ágnes: Budapesti Corvinus Egyetem, Környezetgazdaságtani és Technológiai Tanszék, Budapest; robozagi@gmail.com

BALÁZS Bálint: Környezeti Társadalomkutatók (ESSRG), Gödöllő; balazs.balint@essrg.hu

NYAKAS Szabolcs: közgazdász; szacsi88@gmail.com

KULCSSZAVAK: részvételi akciókutatás, cigányság, társadalmi kirekesztés, térbeli szegregáció, kutatói szerepek

ABSZTRAKT: Nemzetközi felmérések, valamint hazai kutatások egyaránt rámutatnak arra, hogy az európai és a hazai cigány lakosság zöme a társadalom leghátrányosabb helyzetű csoportjai közé tartozik. A cigányság esetében a társadalmi hátrányok és a térbeli szegregáció sok esetben összekapcsolódnak. Tanulmányunk középpontjában a fenti problémához kapcsolódó szegedi esettanulmány áll. 2011 eleje óta részvételi akciókutatási folyamat keretében együttmüködünk helyi roma vezetőkkel és helyi szegregátumokban élő családokkal. Együttmüködésünk célja kettős: kutatóként egyrészt érvényes tudást szeretnénk létrehozni a cigányság (helyi szintű) társadalmi integrációjáról, másrészt e tudást a gyakorlatban is tesztelve szeretnénk közösen hozzájárulni az integrációhoz.

Az elmúlt bő három év során számos kutatási eredménnyel, tapasztalattal gazdagodtunk a helyi társadalmi kirekesztéssel és integrációval, annak területi-térbeli vetületeivel, valamint a helyi politikai döntések és a társadalomtudomány viszonyával kapcsolatban. Tanulmányunkban néhány, a témát érintő általános kutatás-módszertani és -etikai kérdés mellett kitérünk arra, hogyan függ össze a térbeli szegregáció a társadalmi hátrányokkal, hogyan befolyásolják azt a helyi politikai folyamatok, valamint írunk a társadalomkutatással szembeni követelményekről, amennyiben az a részvételi

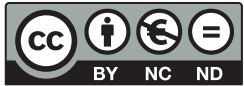


akciókutatás megközelítése mentén a társadalmi integráció kérdésével foglalkozik. Következtetésünk, hogy a részvételi akciókutatás megközelítése a társadalomkutatást új kihívások elé állítja, és a társadalmi integrációval foglalkozó részvételi akciókutatás könnyen azt eredményezheti, hogy a kutató „objektív”, „kívülálló”, „,üggetlen” szakértőből helyi politikai szereplővé válik. Ez azonban nem a szakértői-kutatói szerep megváltozását, pusztán a kutatói szerep mögött szükségszerűen megjelenő érdek- és értéktartalom nyílttá tételét jelenti.

György MÁLOVICS: Community-based Research for Sustainability Association (CRS); associate professor, Faculty of Economics and Business Administration, University of Szeged; malovics.gyorgy@eco.u-szeged.hu

Barbara MIHÓK: Community-based Research for Sustainability Association (CRS), Szeged; akutegyesulet@gmail.com

György PATAKI: Department of Environmental Economics and Technology, Corvinus University of Budapest; Environmental-Social Science Research Group (ESSRG), Gödöllö; Community-based Research for Sustainability Association (CRS), Szeged; gyorgy.pataki@corvinus.hu

István SZENTISTVÁNYI: Community-based Research for Sustainability Association (CRS), Szeged; iszentistvanyi@gmail.com

Ágnes ROBOZ: Department of Environmental Economics and Technology, Corvinus University of Budapest; robozagi@gmail.com

Bálint BALÁZS: Environmental-Social Science Research Group (ESSRG), Gödöllo; balazs.balint@essrg.hu Szabolcs NYAKAS: economist; szacsi88@gmail.com

KEYWORDS: participatory action research, social disadvantages, spatial segregation, researcher roles

ABSTRACT: Large international surveys and regional and national (Hungarian) examinations all show that the vast majority of the European and Hungarian Roma population belongs to the most disadvantaged groups of society. Furthermore, social disadvantages and spatial segregation are often connected.

Our paper is based on a case study carried out in Szeged (Hungary) in relation to the problems mentioned. In Szeged, university researchers and social activists have been working together with local Roma leaders and Roma families living in segregated areas (segregates) from the beginning of 2011 within the framework of participatory action research. As a participatory action research-type research process our cooperation has two strongly interconnected goals. First, we aim to generate valuable knowledge about the social integration of Roma. Second, we aim to contribute to local social integration processes by testing our knowledge in practice through actions in the field.

Based on our ongoing work, we gained valuable research experience regarding local social segregation and integration and its spatial aspects, and the role of scientific research and researchers in this area. In our study we give an overview of these experiences. Besides introducing some general questions and (ethical) dilemmas regarding social science research dealing with social segregation/integration, we examine how social and spatial integration are interconnected and the requirements social scientists have to meet if they deal with social integration issues within the framework of participatory action research .

Our conclusions are that participatory action research sets new challenges for social researchers - because of its action component, for example - and participatory action research dealing with local social integration of the Roma might cause "objective", "outsider" or "independent" researchers turning into local political actors. However, this "turn" does not necessarily mean a real change in the role of experts, but it rather means that interests and values necessarily appearing behind scientific research are made explicit in the process of participatory action research. 


\section{Bevezetés}

A nagy nemzetközi felmérések (FRA 2010; Rorke 2011), valamint a régiós és hazai kutatások (Forray, Mohácsi 2002; KIM Társadalmi Felzárkózásért Felelős Államtitkárság 2011; Ladányi, Szelényi 2004) rámutatnak arra, hogy az európai, illetve a hazai cigányság zöme a társadalom leghátrányosabb helyzetű csoportjai közé tartozik. A helyzet dokumentálásán túl nyilvánvaló kérdésként merül föl a változtatás igénye: a kedvező társadalmi változás kiváltását, segítését előtérbe helyező társadalomkutatási megközelítés a részvételi akciókutatás (participatory action research). Tanulmányunk egy három éve tartó szegedi részvételi akciókutatási folyamatról számol be. Cikkünk első részében ismertetjük a kutatást indukáló társadalmi és akadémiai kontextust és a részvételi akciókutatás folyamatát, eredményeit. Ezután kitérünk arra, hogyan függ össze a térbeli szegregáció a társadalmi hátrányokkal és kirekesztéssel, hogyan befolyásolják azt a helyi politikai folyamatok, valamint írunk néhány olyan kutatásmódszertani dilemmáról, amelyeket a részvételi akciókutatás fölvet a helyi politikai döntések és a társadalomkutatás viszonyrendszerében.

\section{Részvételi akciókutatásunk akadémiai és társadalmi kontextusa}

A részvételi akciókutatás definiálásával, hagyományaival, episztemológiai és ontológiai alapjaival, módszereivel egyre több írás foglalkozik (Bodorkós 2010; Bradbury, Reason 2003; Kindon, Pain, Kesby 2007; Pataki, Vári 2011; Reason, Bradbury 2001). Az akciókutatás klasszikusa (Reason, Bradbury 2001, 1.) szerint e kutatás lényege, hogy „megpróbálja újra összekapcsolni a cselekvést a reflexióval, az elméletet a gyakorlattal, másokkal együttműködésben, az embereket foglalkoztató problémákkal kapcsolatos gyakorlati megoldások keresésére." A részvételi akciókutatás ehhez képest ,a részvételt és a hatalmi viszonyok változását, a közösségeket érintő döntéshozatali folyamatokban való részvételt helyezi középpontjába”, valamint „a lehetőségek szerint az összes releváns szereplőt bevonja a valamilyen szempontból problémásnak ítélt helyzet értékelésének folyamatába abból a célból, hogy változásokat és konkrét cselekvéseket hozzon létre." (Bodorkós 2010, 31., 37.)

A részvételi akciókutatás tehát kifejezetten a kedvező társadalmi változások elóidézése érdekében folyik (Bodorkós 2010; Pataki, Vári 2011), fö alapvonásai, hogy

- a kutatói szerepben részt vevők tudatosan alkalmazzák a tudományos megismerés szabályait,

- a kutatás a részt vevő kutatók és érintettek folyamatos, rendszeres együttműködésén alapul a kutatási kérdések meghatározásától az eredmények publikálásáig, 
- lényegi eleme az akció - a folyamat tehát nem áll meg a kutatási adatok elemzésénél, hanem az eredményekre építve az érintettek javát szolgáló akciókat igyekszik megvalósítani.

Szegedi kutatásunk a térbeli szegregáció és társadalmi kirekesztés vizsgálata során a környezeti vagy térbeli igazságosság fogalmára épít. ${ }^{1}$ A kritikai társadalomtudományok és a földrajztudomány (tértudományok) keresztmetszetében vizsgálódva olyan politikai erőteret érzékelünk, amely a progresszív (transzgresszív, emancipatorikus stb.) társadalmi kezdeményezéseknek a térhasználatért (területhasználatért) folytatott küzdelméről szól. ${ }^{2}$ A térbeli-társadalmi mintázat vizsgálata a szegregátumokban élő szegedi cigányság térbeli elhelyezkedésén túl a település nyújtotta szolgáltatásokhoz (infrastruktúrához, természeti erőforrásokhoz, környezeti javakhoz vagy olyan egyéb szolgáltatásokhoz, mint az oktatás, egészségügyi ellátás, közlekedés, rekreációs lehetőségek stb.) való hozzáférés elemzését jelenti. ${ }^{3}$

A témánk szempontjából meghatározó szegedi felmérések ritkák. Egy 1997-ben készült tanulmány (Rátkai 1997) szerint 2500-3000 cigány ember élt 1996-ban Szegeden, míg jelenleg interjúink alapján a cigányság létszáma 45005000 fö közé tehetö. ${ }^{4} \mathrm{~A}$ városban két nagyobb szegregátum alakult ki (Cserepes sor, dorozsmai telep), illetve maradt fent a mai napig, de a szegedi cigány lakosság többsége a városban elszórtan él. Származásuk és szociális helyzetük szerint igen-igen diverz csoportok alkotják a szegedi cigányságot, a vidékről beköltözők, majd továbbköltözők számának becslése igen nehéz a nagy fluktuáció miatt. Az interjúinkból kirajzolódott kép szerint a rendszerváltozás óta a határozottan növekedő társadalmi előítéletek erősítették a munkaerő-piaci diszkriminációt.

Összegezve: a szegedi cigányság jelentős része társadalmi kirekesztésnek, kisebb részük térbeli szegregációnak van kitéve. A rendszerváltozás óta a szegedi cigányok foglalkoztatottsága nagymértékben csökkent, a marginalizáció ${ }^{5}$ egyre nagyobb csoportokat érint; a felzárkóztatási programok nem hoztak átütő eredményt, a városi politikai elit részéről nincs valódi elkötelezettség a „romakérdés” megoldására; a szegedi cigányok közössége többszörösen tagolt és rétegzett származás és szociális helyzet szempontjából, a közösségen belüli önszerveződés nem jelentős, az összefogást belső ellentétek is akadályozzák.

\section{Részvételi akciókutatás marginalizált roma lakossággal Szegeden}

Munkánkat 2011 februárjában kezdtük. Kezdetben kutatóhelyként a Környezeti Társadalomkutatók (ESSRG), civil szervezetként pedig a Védegylet szegedi csoportja működött közre; majd a közös munka során a résztvevők köre és szerepei megváltoztak (1.ábra). 
1. ábra: A szegedi részvételi akciókutatás folyamata

The process of participatory action research in Szeged

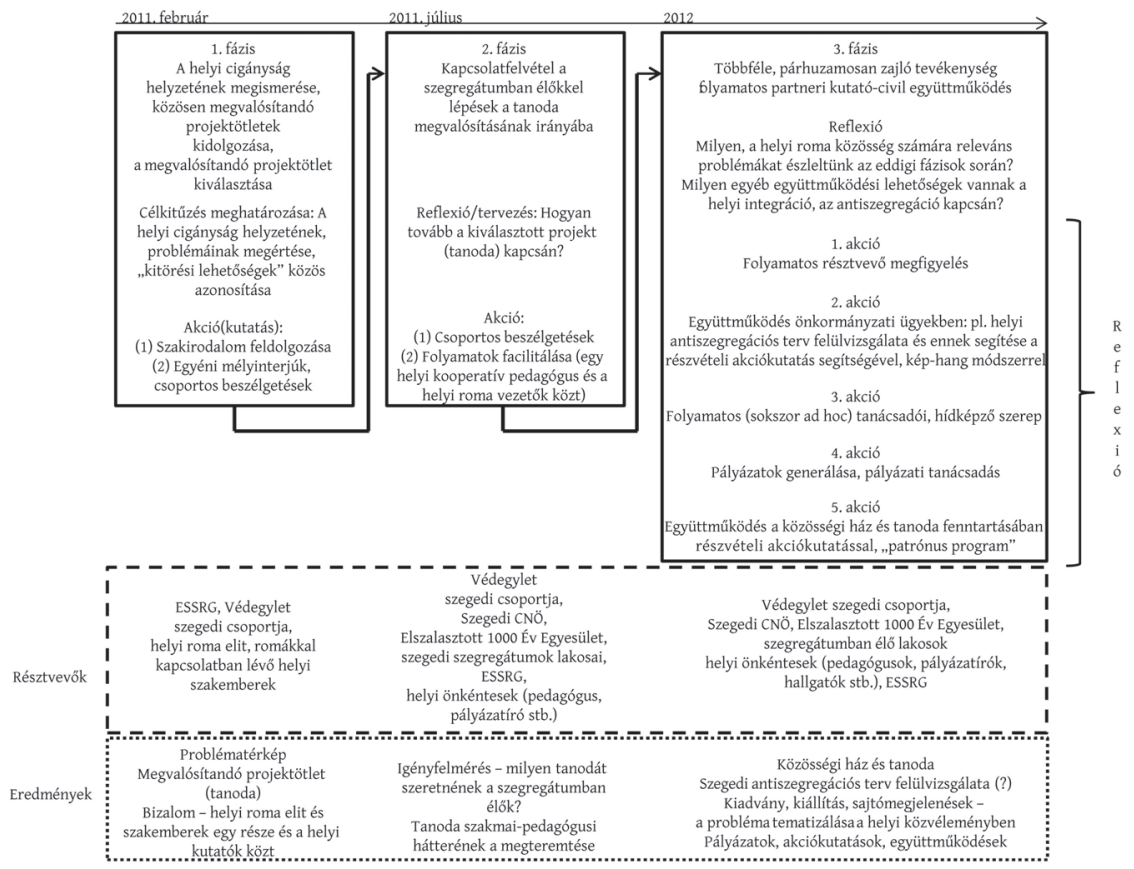

A részvételi akciókutatás folyamata során az akció és a reflexió fázisai követik egymást. Optimális esetben a kutatás minden egyes fázisában a kutató és az érintett résztvevők közösen és szisztematikusan reflektálnak az egyes cselekvésekre - a kutatás megtervezésétől a kutatási eredményeket létrehozó cselekvésen át a teljes folyamat végső értékeléséig. Ez biztosítja, hogy a kutatás teljes folyamata során megjelenjen mind a helyi, érintetti tudás (és az ő szempontjaik), mind pedig a kutató résztvevők (akadémiai) tudása, valamint hogy a kutató döntéseit nagyon tudatosan (állandó önkritika mellett) hozza meg, továbbá ezeket és következményeiket átláthatóvá tegye, tudatos módon kezelje. $\mathrm{E}$ munkafázisok irányt szabnak a részvételi akciókutatás folyamatának: egyrészt az adott munkafázison belül (pl. az alkalmazott kutatási módszerekről, a bevonni kívánt érintetti körről stb.), másrészt pedig a munkafázisok közt (ha egy munkafázis lezárul, hogyan folytassuk a részvételi akciókutatási munkát).

\section{A projekt első fázisa: a szakértői elit szakasz}

A projekt első szakaszában a részvételi akciókutatás és a cigányság szakirodalmának áttekintésével gyakorlatilag egy időben elkezdtük a terepmunkát is. ${ }^{6} \mathrm{Az}$ 
első kihívás az volt számunkra, hogy kapcsolatba kerüljünk a helyi cigánysággal és igyekezzünk az ő helyzetükről, belső viszonyrendszerükről lényeges információkat szerezni (helyzetüket a körülmények adta lehetőségekhez képest megérteni).

E célokból kifolyólag félig strukturált egyéni mélyinterjúkra alapozott kvalitatív kutatás mellett döntöttünk, a helyi cigány vezetőkkel, valamint szakemberekkel és a cigányság ügyével foglalkozó szakemberekkel. Az interjúk elemzésből rövid összefoglalót készítettünk. Az összefoglalót meghívóként használva meghívtuk összes korábbi interjúalanyunkat egy csoportos beszélgetésre (fórumra), hogy ötleteket kapjunk ahhoz, milyen akciók (tevékenységek, projektek) segítenék leginkább a helyi roma közösséget. A fórumon a közös munka folytatásához további kutatási, illetve projektötleteket nyertünk. Második fórumunk célja a felmerült projektötletek közül egy vagy két közösen megvalósítandó projekt kiválasztása volt. Az interjúkban és az első fórumon fölmerült ötletek közül ötöt összefoglaló anyagként eljuttattuk az interjúalanyoknak, majd azokat a második fórumon bemutattuk és a jelenlévőkkel megvitattuk. Ezek után a megjelentekkel közösen az öt ötlet egyikét, egy roma tanoda létesítését választottuk ki megvalósításra.

Folyamatos közösségbeli jelenlétünk lehetővé tette, hogy elkezdjen kialakulni a bizalmi viszony köztünk, kutatók, illetve az érintettek egyes képviselői közt. Egy ilyen típusú, az egymás iránti bizalomra épülő kapcsolat megteremtése alapvető feltétele a részvételi akciókutatás sikerének (Smith, Brazini, Chambers, Jansen, Romero 2010), már csak a munka együttműködő jellegéből fakadóan is.

\section{A részvételi akciókutatás második fázisa: a tanodai program elökészitése a szegedi szegregátumokban}

Munkánk második szakasza 2011 nyarán indult, immár a cigányság ténylegesen marginalizált helyzetben lévő részével (a szegregátumokban élőkkel) együtt dolgozva. Az első körben szerzett kapcsolatainkon keresztül szerveztünk két teleplátogatást, ahol a helyiek véleményét kérdeztük (többek között) a tanodával kapcsolatosan - résztvevő megfigyelés jelleggel. 2011 októberében két fórumot szerveztünk, amelyeken megtudtuk, hogy az érintett családok milyen feltételek mellett képesek és hajlandóak aktívan részt venni egy tanodai típusú programban. Később újabb két fórumot szerveztünk a szegregátumokban, amelyeken visszacsatolást kértünk a megjelentektől, milyen igényekkel rendelkeznek egy tanodai programmal kapcsolatban. ${ }^{7}$

E fázis eredményeképpen rendelkezésre álltak az érintett családok tanodai programmal kapcsolatos igényei, meglátásai. A résztvevők köre is változott a korábbiakhoz képest. Bekerültek a munkába a szegregátumokban élők, akikkel közösen terveztük a tanodai programot. A helyi cigányság részéről az első, szakértői elit csoportból csupán 2-3 fö maradt - azok, akik a helyi Cigány Nemzeti Önkormányzat (CNÖ) képviseletében, illetve annak önkénteseként tevékenykedtek. Ennek egyik oka, hogy hamar kiderült: a korábbi és jelenlegi helyi 
roma vezetők nem akarnak egymással dolgozni - egyebek mellett a részvételi akciókutatáson belül sem. Így kutatásunkban olyan ponthoz érkeztünk, amikor döntenünk kellett arról, hogy kivel működünk együtt a továbbiakban. Végül az akkor - és jelenleg is - hivatalban lévő szegedi CNÖ és egy helyi roma egyesület tagjaival folytattuk a munkát. Ennek oka, hogy az egymással együttműködni nem szándékozó potenciális roma partnerek közül - addig felhalmozódott tapasztalataink alapján - az ő megítélésük volt helyben kedvezőbb, valamint ők voltak azok, akik részéről az akció felé komolyabb elszántságot, együttműködési szándékot - illetve általában a helyi cigányság helyzetével kapcsolatos mélyen elkötelezett, jobbító szándékot - észleltünk. Mások az elvileg együttműködésre nyitott és egymással együttműködni képes szereplők közül pedig azért kerültek ki az akciókutatási folyamatból, mert célunk az volt, hogy közvetlenül a marginalizált helyzetben lévő roma közösséggel dolgozzunk együtt, ami mellett csoportunknak nem maradt energiája arra, hogy azokat, akikkel nem dolgoztunk közvetlenül együtt, bevonjuk a részvételi akciókutatás további folyamatába.

E tapasztalatokból legalább két következtetést vonhatunk le. Egyrészt egy részvételi akciókutatási projektben az emberi viszonyok és az ügy iránti elkötelezödés kulcsfontosságúak. Egy ilyen együttműködés nagyon sok önkéntes munkát igényel, így azt csak mély érzelmi-morális elköteleződés mellett lehetséges csinálni. Ehhez olyan résztvevők kellenek, akik egymással önkéntes alapon is képesek együtt dolgozni, elköteleződésük mellett egymással személyesen is jó viszonyt ápolnak. Az, hogy egy közösségbe kívülről érkező kutató milyen viszonyt képes kialakítani az ajtónállókkal (gatekeeperekkel), alapvető befolyással van a részvételi akciókutatás minőségére. A szegregált roma közösségekben pedig jó eséllyel találkozunk ajtónállókkal, ha más miatt nem, a hazai nemzetiségi önkormányzati rendszer vagy éppen az uzsora jelensége miatt.

Másrészt egy hosszabb részvételi akciókutatási folyamatban a résztvevők köre és a részvétel minősége akár viszonylag gyakran is változhat (Chung, Lounsbury 2006), a részvételnek különböző szintjei alakulhatnak ki, amelyek egymással párhuzamosan léteznek. Esetünkben a szegedi CNÖ vezetőjével sokszor napi, de minimum heti kapcsolatban vagyunk, a szegregátumban élőkkel pedig heti-havi gyakoriságú a viszonyunk.

\section{A részvételi akciókutatás harmadik fázisa: a folyamatos kutatócsoport-közösség együttmüködés}

A kutatás második szakaszának végére lezárult a projekt, amely finanszírozást biztosított a munkához. A részvételi akciókutatási folyamat azonban nem állt le, mivel az eredetileg tervezett tanodai programot még nem sikerült megvalósítani. Ettől függetlenül a projekt végével kutatóként „elhagyhattuk volna a terepet”, de nem ezt tettük. Ennek oka, hogy egy ilyen típusú munka a marginalizált közösségben reményt kelt. Mindez a többségi társadalomból érkező kutató szereplőkben 
felelösségérzetet, érzelmi elkötelezettséget szült, ami miatt morálisan vállalhatatlan döntés lett volna érdemi társadalmi eredmények nélkül befejezni a munkát.

Ekkorra a részvételi akciókutatásban betöltött szerepünk is átalakult. Együttműködő partnereink nem egy projektre szerveződött csapatként tekintettek ránk, hanem olyan helyi, többségi társadalmi szereplőkként, akik segítenek nekik. Így az irányunkba érkező elvárások a szegedi cigányság társadalmi integrációjával kapcsolatos általános „segítői” elvárássá alakultak át. Részvételi akciókutatásunk elkezdett a cigányság társadalmi integrációjával kapcsolatos területekre is kiterjedni.

\section{Részvételi akciókutatás a tanodai programhoz kapcsolódóan}

2012 őszére sikerült elkezdenünk az addigi folyamatban kiválasztott tanodai programot (Mihók, Roboz, Nyakas, Szentistványi, Málovics 2012). Ennek megvalósításában, illetve az azóta tartó múködtetési folyamatban az alábbi szerepeink voltak (vannak):

- ösztönző szerep helyi pedagógusok irányába,

- tanácsadó, ösztönző, érdekérvényesítő szerep a helyi önkormányzat irányába (pl. segítség az infrastruktúra megszerzésében), valamint

- folyamatos „tanácsadói” és segítői szerep a tanoda működésével kapcsolatban (a tanodai program működtetése során folyamatosan merülnek fel kérdések és problémák, ezekben igyekszünk jelenleg is segíteni partnerünknek).

\section{Antiszegregációs érdekérvényesités a helyi önkormányzat felé}

A részvételi akciókutatás tárgya, azaz az érintettek integrációját célzó segítés a közösség tagjai által fogalmazódott meg és fogalmazódott át markánsan, mi pedig erre reflektálva terveztük tovább a kutatási, együttmüködési folyamatot. Így együttműködésünk azzal a céllal folytatódott, hogy a szegedi cigányság marginalizált helyzetben lévő részének társadalmi helyzetét javítsuk. Amikor e céllal kapcsolatban az érintettektől kérés érkezik, rendszeresen segítünk, együtt gondolkodunk, „tanácsot adunk” a helyi cigány vezetőknek helyi roma érdekérvényesítési ügyekben. Ez testet ölthet beadványok vagy sajtóüzenetek megfogalmazásában, közös sajtószereplésekben, vagy egyszerűen csak a cselekvési lehetőségek közös megvitatásában.

Másrészt a részvételi akciókutatás folyamata során világossá vált számunkra, hogy a szegedi politikai elitnek az a része, amelyik tényleges döntéshozói hatalommal rendelkezik, a probléma nagyságához és bonyolultságához képest nagyon keveset tett és tesz a szegedi cigányság társadalmi helyzetének javításáért, sőt sokszor ellenérdekeltnek tűnik a problémák megoldásában. Legszorosabb együttműködő partnerünk, a szegedi CNÖ vezetője a helyi politikai életben kifejezetten aktív szereplő, ${ }^{8}$ akit ennek megfelelően segítünk abban, hogy a helyi cigányság érdekképviseletét ellássa a helyi önkormányzatokban. Együttmüködésünk kiterjed a tanácsadásra, egy újabb részvételi akciókutatási 
projektre (kép-hang módszer) (Catalani, Minkler 2010), illetve az önkormányzati bizottsági munkában való együttműködésre. ${ }^{9}$

\section{Segitség újabb projektek létrehozásában}

Erőforrások (pályázati tapasztalat, emberi és anyagi erőforrások) hiánya miatt együttműködő partnerünk sokszor nem tudott élni pályázati lehetőségekkel. Így kutatócsoportunk több pályázatban is támogatta és támogatja az érintetteket ötletgazdaként, valamint ösztönzői és hídképző szerepben.

\section{Reflexió: honnan hová jutottunk?}

Cikkünk e részében két szempontból reflektálunk eddigi eredményeinkre. Elöször körüljárjuk, hogy a területi szegregáció és a (helyi) politikai folyamatok milyen szerepet játszanak a társadalmi hátrányok kialakulásában, fennmaradásában, hogyan befolyásolják az ezek elleni küzdelmet. Másrészt elemezzük, hogy melyek a feltételei az érvényes és használható antiszegregációs tudás létrehozásának, és mi ebben a kutató, a tudományos kutatás szerepe.

\section{Területi szegregáció és társadalmi hátrányok}

A területi szegregáció több síkon is megnehezíti a társadalmi hátrányok elleni küzdelmet. Az egyik a „konkrétumok” síkja: a szegregátumokban nagyon nehéz anyagi, lakhatási, egészségügyi, higiéniai stb. helyzetben élnek az emberek (Málovics, Mihók, Szentistványi, Balázs 2011), ami önmagában is megnehezíti a munkavállalást, munkavégzést, iskolába járást, tanulást stb.

Kevésbé közvetlenül hat az a jelenség, amelyet az integrációs elméleteken (Farkas 2008, 2012) keresztül érthetünk meg. A társadalmi integráció két oldalát különböztethetjük meg: a szociális és a rendszerintegrációt. A szociális integráció a családhoz, ezen keresztül a rokonsági hálózathoz, szomszédsághoz, lakókörnyezethez, baráti kapcsolatrendszerhez kötődik (Farkas 2012). Ha egy szociális közösség térbeli (és társadalmi) értelemben szegregált, akkor az hozzájárulhat ahhoz, hogy a kisközösségi életvilágok partikuláris (a többségitől, az „univerzálistól” eltérő) értékekre, szabályokra, életstratégiákra, normákra épüljenek - ez viszont megnehezíti a rendszerintegrációt.

Utóbbi a különböző társadalmi intézményeken, szervezeteken, illetve az azokban való jelenléten keresztül valósul meg. Az utóbbi évtizedekben ennek legfontosabb dimenziója a munkamegosztásban történő részvétel és a (köz)oktatás (Farkas 2012).

A területileg szegregált életmód azt eredményezi, hogy az adott szegregátum nagyon erős szociális integrációs közegként működik, ami sokszor megne- 
hezíti a rendszerintegrációban való részvételt. A szegregált életmód erős belső (szocializációs) kötéseket eredményez, amelyek egyfelől társadalmi tőkeként (Coleman 1994) erőforrásokat biztosíthatnak az érintettek számára, másrészt viszont kockázatokat is rejthetnek magukban, amennyiben nagyon erőteljes, a rendszerintegrációt esetlegesen akadályozó partikuláris szabályokat, értékeket hordoznak. Ilyennek tünik a gyermekek, különösen a fiúgyermekek családban betöltött helye, szerepe a szegregált körülmények közt élő családokban. Ez jelentősen eltér a többségi társadalom modelljétől, ami többek között gyermeknevelésbeli különbségeket is eredményez, ez pedig befolyással lehet a gyerekek iskolai viselkedésére, teljesítményére. Szintén ilyen lehet a (mély)szegénység kognitív képességeket rontó hatása (Mani, Mullainathan, Shafir, Zhao 2013).

\section{Társadalmi integráció és (helyi) politikai folyamatok}

A cigányság társadalmi integrációjával foglalkozó részvételi akciókutatási folyamat szükségszerüen politikai folyamat. Egyrészt azért, mert az sokszor a közügyekbe való beavatkozás, bizonyos értékek és érdekek mentén. A cigányság integrációjára irányuló részvételi akciókutatás politikai tevékenység azért is, mert szükségszerűen helyi politikai szereplők megjelenésével jár, legalább két síkon.

Az egyik a cigány nemzetiségi önkormányzatok szerepe. Ezek a részvételi akciókutatás folyamatában ajtónállóként jelennek meg - a kutató gyakorlatilag nem kerülheti meg a formális helyi roma vezetőket a cigányság integrációját érintő részvételi akciókutatási folyamatban. Ez pedig komolyan befolyásolhatja a részvételi akciókutatás folyamatát. Befolyásolja például a kutató felé az érintettektől érkező elvárásokat. A szegregált körülmények között élő roma lakosok a CNÖ-re sokszor mint „segélyszervezetre” tekintenek - azaz elvárják, hogy az rövid távú, aktuális, napi problémáikban és szükségleteik ellátásában (étel, tüzelö, ruha stb.) lehetőség szerint segítsen. Ez a CNÖ-knek - azok eszköztelensége, az alapvető emberi és anyagi erőforrások szinte teljes hiánya miatt vagy azért, mert az érintettek elvárása, hogy a CNÖ mindenkinek „egyenlően” adjon, ami sokszor megoldhatatlan feladat - sokszor nem sikerül. Ez a helyiek körében konfliktusokat és elégedetlenséget szülhet, ami pedig befolyásolhatja a részvételi akciókutatási folyamatot, mert az érintettek szemében nem feltétlenül válik el a CNÖ - mint az érdekképviseletért felelős szervezet - és az együttműködő partnerek.

Ezen túlmenően a CNÖ-k léte szinte szükségszerűen pártpolitikai mezőbe tereli a részvételi akciókutatás folyamatát. Ennek oka, hogy jó eséllyel a helyi cigány nemzetiségi önkormányzati rendszerben is leképeződik a hazai kettős (jobb és bal, FIDESZ és MSZP) pártpolitikai berendezkedés, azaz a CNÖ-k is „tartoznak valahová”. Ez pedig azt eredményezi, hogy a CNÖ szükségszerüen kapcsolatban van a helyi önkormányzattal, a helyi politikai elit a CNÖ-kre vagy szövetségesi, vagy pedig rivális politikai erőként tekint. 
Továbbá a cigány-magyar együttélés, a roma integráció nagyon átpolitizált, közérdeklődésre számot tartó „téma”. Ennek fő oka, hogy a cigányság az egyik leginkább előítéletesen kezelt társadalmi csoport (Fábián, Sik 2006).

A fentiekből fakadóan azt tapasztaljuk, hogy a helyi CNÖ és a helyi politikai elit között sajátos viszony alakul ki, továbbá a helyi politikai elit „kettős játékot” folytat a helyi roma integrációt célzó kezdeményezések kapcsán.

Egyrészt a hatalmon lévők (ahogyan interjúalanyaink nevezték: a „nagy önkormányzat”) egyből besorolják a CNÖ-t saját politikai ellenfeleik vagy szövetségeseik táborába. Másrészt a cigánysággal kapcsolatos előítéletek miatt a helyi politikai elitnek - jellemzően egységesen - az az érdeke, hogy a téma „ne legyen napirenden", ez ugyanis könnyen népszerüségvesztést (szavazatvesztést) eredményezhet. ${ }^{10}$ Ugyanakkor tudják: papíron foglalkozniuk kell a témával, a 21. század Európájában azt a mindenkori politikai hatalom nem teheti meg, hogy ne tegyen úgy, mint ha a cigányság integrációjának (a szegénység felszámolásának, az emberi jogoknak, az alapvető emberi szükségletek kielégítésének stb.) „élharcosa” lenne. Így könnyen a következő logika érvényesülhet: a helyi politikai elit számára a legkényelmesebb az, ha a cigány-magyar együttélés kérdése nincs napirenden, ha viszont mégis napirendre kerül, akkor el kell azt hitetni a közvéleménnyel, hogy a helyi politikai hatalom sokat tesz a problémák megoldása (azaz a helyi emberek) érdekében.

Ez pedig meghatározza a CNÖ-k szerepét és mozgásterét. A CNÖ addig tarthat fent kooperatív kapcsolatot a „nagy önkormányzattal”, amíg együttmüködik azzal, annak szándékainak megfelelően. Ebben az esetben viszont - mivel a „nagy önkormányzat” a téma „homályban” tartásában érdekelt - a CNÖ nem képes valódi érdekképviseletre, hanem a „nagy önkormányzat” igényeinek kiszolgálójává válik. Másrészt amennyiben a helyi CNÖ tényleges politikai érdekképviseletbe kezd, az egyből és közvetlenül a „nagy önkormányzattal” való konfliktusokhoz, ellentétekhez vezet.

Ugyanez igaz a részvételi akciókutatásban részt vevő kutatókra is: ha tevékenységükkel politikai érdekeket sértenek és e megfigyeléseket helyben „publikálják", akkor kénytelenek konfliktusokat magukra vállalni a helyi politikai elittel szemben. A cigányság társadalmi integrációját célzó részvételi akciókutatási folyamatban részt vevo” kutató könnyen (szinte szükségszerüen?) a kényelmes „objektív, sérthetetlen, láthatatlan" szakértöi-kutatói szerepböl kikerülve helyi (köz)politikai szereplövé válik.

\section{Részvételi akciókutatás, antiszegregációs tudás, kutatói szerepek}

Nyilvánvaló, hogy a szakértői tudás gyakran szolgálja helyi fejlesztési, politikai döntések megalapozását. A helyi beruházásokhoz például sok esetben helyi szakértők - akár „egyetemi emberek” - írnak megvalósíthatósági tanulmányokat vagy azok részeként készítenek költség-haszon elemzést stb. Munkánk során 
számtalan tapasztalattal gazdagodtunk arról, hogy mi lehet egy társadalomkutató szerepe a helyi politikai döntésekkel kapcsolatos tudás létrehozásában. $\mathrm{Az}$ alábbiakban néhány fóbb kérdés mentén e tapasztalatokról számolunk be.

\section{Helyi politikai döntések és hasznos, érvényes tudás}

Munkánk során bennünk is többször fölmerül(t) a kérdés, hogy mi a hasznos, érvényes tudás a helyi politikai döntésekkel kapcsolatban. Mennyiben befolyásolják e tudás érvényességét és megbízhatóságát a diszciplináris szabályok és mennyiben a hasznosíthatóság, a társadalmi problémák megoldására való alkalmasság? Érvényesnek tekinthető-e az a - például a (helyi) társadalmi problémák megoldásával, (helyi) fejlesztési döntésekkel kapcsolatos - tudományos tudás, amely nem állta ki a gyakorlati alkalmazhatóság próbáját? ${ }^{11}$

A részvételi akciókutatás szerint egy kutatási folyamat tudományos és társadalmi minősége szorosan összefügg. Ha a tudományos munka értékét kizárólag konvencionális eszközökkel (publikációk száma, hivatkozások) mérjük, akkor előfordulhat, hogy a tudományos és a társadalmi hasznosság elválik egymástól - azaz tudományos értelemben sikeres kutatók kevés, a gyakorlati problémamegoldás szempontjából releváns tudást hoznak létre. Saját magunkra reflektálva: tudományos eredményeinkről már akkor is nemzetközi konferencián számolhattunk be, amikor annak társadalmi hatása még egyáltalán nem jelentkezett.

A részvételi akciókutatás így a tudományos sikerességnél többet követel meg ahhoz, hogy hasznos, érvényes tudásról beszélhessünk. Egyrészt a részvételi akciókutatás akciókomponense miatt a létrehozott tudásnak át kell mennie a müködóképesség tesztjén. A társadalomkutatást ért legalapvetőbb kritikák egyike, hogy „az emberek közbeavatkozhatnak” (Babbie 2008), azaz a feltárt (a kutató által valamilyen primer módszerrel kiderített) preferenciák eltérnek a kinyilvánított preferenciáktól (azaz a valós cselekvésektől). A részvételi akciókutatás e problémára megoldást ad az akciókomponenssel.

A müködőképesség tesztjének fontossága számunkra is nyilvánvalóvá vált. Megértettük például, hogy a szegregátumokban élő gyermekeknek létesített tanodai program üzemeltetése során számtalan olyan szempont megjelenik, amely egy előzetes kvalitatív kutatás során nem feltétlenül kerül felszínre - a kutató és a marginalizált érintettek eltérő perspektívájától kezdve egészen az érintett közösség belső konfliktusáig. A politikai akciók, az érdekérvényesítés során pedig föltárult számtalan politikai-intézményi akadály (lásd az előző részt), amelyek politikai döntéshelyzetben akadályozzák a társadalmi integrációt vagy a tudományos tudás gyakorlatba való átszűrődését.

Szintén komoly gondot jelent az eredmények értékelésénél az időtáv problémája. Egyáltalán nem evidens, hogy milyen időtávon ítélhető meg például a részvételi akciókutatás sikeressége, a siker mértéke. Mi van akkor, ha a ma sikeres(nek tűnő) kezdeményezések néhány éven belül zátonyra futnak? S ha ennek következtében az érintett közösség rosszabb élethelyzetbe kerül, mint volt a beavatkozás elött? Az időtáv értékelésével összefüggésben különösen ko- 
moly dilemmákat vet föl, ha a részvételi akciókutatás fókusza a társadalmi helyzet javítása, a marginalizált helyzetben lévők társadalmi helyzetének javítása ugyanis nem rövid távú folyamat. Nyilvánvaló, hogy a társadalmi helyzet javításának egyes alapvető feltételei, az iskolai, munkaerő-piaci stb. hátrányok kompenzálása nem mennek egyik pillanatról a másikra - így az eredmények egyrészt nem feltétlenül jelentkeznek rövid távon, másrészt a rövid távon jelentkező eredmények könnyen lehet, hogy hosszabb távon nem jelentenek valós társadalmi integrációt.

\section{Helyi politikai döntésekkel kapcsolatos tudás és a társadalomkutató szerepe}

Kérdés továbbá, hogy mi a társadalomkutató szerepe a tudás létrehozásában; azaz milyen kutatói hozzáállással lehetséges érvényes tudást létrehozni (Smith, Brazini, Chambers, Jansen, Romero 2010). „Objektivitásra”, „értéksemleges” megértésre kell-e törekednie a társadalomkutatónak vagy megengedhetö-e bizonyos fokú érzelmi elköteleződés a kutatási probléma iránt? Szintén kérdéses, hogy kinek a tudása számít a tudás létrehozásának folyamatában. Vajon fölérendeltje-e az akadémiai tudás a helyi tudásnak vagy a kettő egymást kiegészíti és nincs értelme azokról hierarchikus rendszerben gondolkodni?

A kutatói szerepekről és az „objektivitásról” a részvételi akciókutatás kettős módon fogalmaz. Egyrészt a részvételi akciókutatás ismeretelméleti szempontból a kritikai szubjektivitásra alapoz (Bodorkós 2010). Ennek értelmében a kutató elfogadja, hogy tudása valamilyen nézőpontból adódik, aminek tudatában van - ezt hivatottak biztosítani a részvételi akciókutatás akció-reflexió fázisai -, és ezt kifelé is megjeleníti. A részvételi akciókutatás tehát nem hisz a tudomány "objektív”, „értéksemleges” mivoltában (Bradbury, Reason 2003).

Másrészről a részvételi akciókutatás alkalmazza a társadalomkutatás alapvető minőségbiztosítási eszközeit, azaz megfelel a tudományos megismerés szabályainak. Bár a részvételi akciókutatásban gyakorlatilag bármilyen társadalomkutatási primer módszertan alkalmazható (Kindon, Pain, Kesby 2007), a folyamat együttműködő jellegéből fakadóan fókuszában jellemzően a csoportos kvalitatív módszerek állnak. A részvételi akciókutatás döntően megértő módszertanokat alkalmaz, és így maga is megértő jellegű megközelítés. Végül az akciókomponens miatt a kutató nemcsak megfigyel, leír, elemez, hanem be is avatkozik társadalmi jelenségekbe.

A fentiekből fakadóan a részvételi akciókutatásban a kutató szerepe kettős (Levin 2012): egyszerre kell távolságtartó, „kívülálló” kutatói és elkötelezett aktivista szerepben részt vennie a folyamatban. Vagyis elkötelezettsége, bevonódása ellenére képesnek kell lennie a folyamatot attól eltávolodva, mintegy külső megfigyelőként szemlélni, elemezni, kritikailag értelmezni. Ez sok esetben nem könnyü. Amikor például a kutató megtapasztalja, hogy a szegregált környezetben, mélyszegénységben élő gyermekeknek milyen nehézségekkel kell megküzdeniük, ha az iskolában középosztálybeli társaikhoz hasonlóan szeretnének teljesíteni, és hogy azok a döntéshozók, akik ez ellen tehetnének, 
mennyire érzéketlenek ezen élethelyzetekre, sőt bizonyos esetekben még el is lehetetlenítenek segítő kezdeményezéseket, és így a kutató már-már egy „kasztrendszerrel" találja magát szembe, akkor kétségkívül nehéz a távolságtartás. Ez azonban a részvételi akciókutatás kihívása, nehézsége, de az ebből adódó érzelmi elkötelezettség miatt annak reményteljessége, szépsége is egyúttal.

Ilyen kettős szerepben, a reflexív részvételi akciókutatási folyamatban a kutató megérti, hogy amit tesz, azt egyrészt tudományos igényességgel teszi, másrészt tette nyilvánvalóan nem érték- és érdeksemleges és bizonyos társadalmi célok elérésére irányul - esetünkben pl. a társadalmi integrációra, a szegregációs helyzetek megszüntetésére. Így a részvételi akciókutatásban a kihívás a tudományos szigor és a társadalmi relevancia kiegyensúlyozása (Levin 2012). Mivel a kutatás valós életvilágokban, helyzetekben folyik, sokszor nehéz olyan módszertani szigort biztosítani, mint amelyet a konvencionális tudományos normák elvárnak. ${ }^{12} \mathrm{~A}$ részvételi akciókutatás ezért a kutatók részéről egyrészt rugalmasságot (Smith, Brazini, Chambers, Jansen, Romero 2010; Smith, Romero 2010), másrészt a kutatási folyamattal és eredményekkel kapcsolatos szigorú önreflexiót követel meg.

Végül a részvételi akciókutatás megközelítéséből fakadóan együttműködő, és ilyen értelemben a szakértői és laikus tudást egymást kiegészitö jellegünek tartja. Egy hosszabb távú, érdemi együttműködésen alapuló folyamat esetében a szakértő-laikus viszony olyannyira elmosódik és megkérdőjeleződik, hogy nehéz az eredményeket „felosztani” az egyes szereplők között (Bodorkós 2010). Nagyon nehéz lenne tehát azt megítélni, hogy egy-egy megállapítás, kezdeményezés, esemény, projekt stb. kinek és milyen arányban köszönhető. Sőt, egy ilyen típusú megkülönböztetésnek nem sok értelme van, lévén egy valódi együttmüködő részvételi akciókutatásban az eredmények közösek - azaz azokhoz mindegyik részt vevő fél hozzájárulása szükséges.

\section{Összegzés}

Tanulmányunkban egy 2011 eleje óta folyó részvételi akciókutatási folyamatról számoltunk be, amelyben a helyi roma közösséggel, elsősorban annak egyes vezetőivel működünk együtt a helyi cigányság társadalmi integrációja érdekében. Bár a társadalmi integráció időtávja meglehetősen hosszú, így kutatásunk időtartama - bár az a konvencionális kutatásokéhoz képest akár hosszúnak is tűnhet - bizonyos értelemben meglehetősen rövid az eredmények értékeléséhez, tapasztalataink alapján azt mondhatjuk, hogy a részvételi akciókutatás annak megértő, együttműködő és cselekvésorientált jellegéből fakadóan olyan megközelítésnek tűnik, amelynek szerepét érdemes mérlegelni a társadalmi integrációval - illetve általánosságban a helyi politikai döntéshozatallal - kapcsolatos tudástermelés és beavatkozások esetében. 
Fontosnak tartjuk hangsúlyozni, hogy a részvételi akciókutatás a társadalomkutatást (és a kutatót) új kihívások elé állítja. Megkérdőjeleződik az értékés érdeksemleges tudásteremtés lehetősége, az akadémiai tudás felsőbbrendüsége más tudásformákhoz képest, a "távolságtartó”, beavatkozástól mentes kutatói hozzáállás - a részvételi akciókutatásban az akciókomponens egyszerre jelenti a létrehozott tudás működőképességi tesztjét és teremt lehetőséget új típusú megismerésre, tudás létrehozására.

A fentiekből is következően a társadalmi integrációval foglalkozó részvételi akciókutatás könnyen azt eredményezheti, hogy a kutató „objektív”, „kívülálló”, „független” szakértőből helyi politikai szereplővé válik. Ez azonban nem a szakértői-kutatói szerep megváltozását, pusztán a kutatói szerep mögött szükségszerűen megjelenő érdek- és értéktartalom nyílttá tételét jelenti - és a kutató számára lehetővé tesz egy új típusú, gyakorlatorientált, mélységi megismerést a helyi (városi) folyamatokról.

\section{Köszönetnyilvánítás}

A szerzők ezúton szeretnének köszönetet mondani a szegedi cigány közösség tagjainak, a szegedi Cigány Nemzetiségi Önkormányzat tagjainak, az Elszalasztott 1000 Év Közhasznú Egyesületnek, interjúalanyaiknak a kutatásra és a közös munkára szánt idejükért és lelkesedésükért. Köszönet illeti a kutatás első fázisában részt vevő Jakab Lászlót és Lakatos Elizabethet, valamint minden önkéntest, akik munkájukkal részt vettek, részt vesznek a bemutatott szegedi integrációs folyamatban. A szerzők munkáját segítette a Public Engagement with Research and Research Engagement with Society (PERARES) elnevezésű európai uniós FP7-es kutatási program (No. 244264, 2007-2013) Local human rights elnevezésü, 6. munkacsomagja, amelyet a Környezeti Társadalomkutatók (ESSRG) irányítottak. Köszönet illeti az ESSRG kutatócsapatát, kiemelten Bela Györgyit támogató munkájáért. A cikkben szereplő esetleges hibákért, hiányosságokért kizárólag a szerzők felelősek.

Jelen tanulmány részben az OTKA K 109425 projekt (A helyi gazdaságfejlesztés megalapozása a képességszemlélet segítségével) keretében készült.

\section{Jegyzetek}

1 Ezt a ,jogközpontú megközelítést” több helyen is megtaláljuk részletesen kifejtve. Sachs (2003) a létfenntartási alapjogokat (subsistence rights) tárgyaló megközelítése például mérsékeltebb, Henri Lefebvre (1993) „a városhoz való jog” követelése radikálisabb alapállást tükröz, mivel nem elégszik meg az egyszerü részvétellel (jelenléttel), hanem a város életének tényleges alakítását, a területek „kisajátítását” propagálja. Környezeti igazságosságról 30 éve kezdtek szisztematikusan beszélni, először észak-amerikai kontextusban (az afroamerikaiak lakta városrészek környezeti ártalmaknak való kitettsége kapcsán - elsősorban Bullard nyomán), majd egyre inkább kiterjesztett értelemben. A térbeli igazságosság (spatial justice) fogalmát joggal szokták Sojához kötni, de a megközelítés eredetileg többek között Lefebvre-nek (és az ő térfelfogásának) is köszönhető - és nem független David Harvey 1970-es években bevezetett területi igazságosság (territorial justice) fogalomhasználatától (Harvey 1973). A „social geography” mellett a 
„social/critical cartography” megnevezés is jelzi a kritikai elméletek hatását ezen a területen. Annak, hogy ez a folyamat jelenleg hol tart, rövid, de lényegi összegzését adja Móricz Ádám (2012) Edward W. Soja legutóbbi könyvének (Seeking spatial justice, 2010) recenziója kapcsán. Ilyen értelemben munkánk közel áll a kritikai városkutatáshoz (lásd Jelinek, Bodnár, Czirfusz, Gyimesi 2013).

3 Ezt az elméleti keretezést (is) használja például Tousek (2012) a csehországi romák térbeli szegregációja kapcsán.

4 A cigányság fogalmával kapcsolatos definíciós nehézségeket, a cigányok köre meghatározásának nehézségeit jelen publikációban nem tárgyaljuk, erről jó és friss áttekintést nyújt Mező (2013). Mi a részvételi akciókutatás folyamata során olyan emberekkel dolgoztunk együtt, akik önmagukat cigánynak tartják, valamint környezetük is annak tartja őket.

5 Tanulmányunkban a marginalizáció, kirekesztés, szegregáció fogalmakat - leegyszerüsítő módon - szinonimaként használjuk, ezeken Ferge (2003) alapján olyan élethelyzeteket értve, amikor valamely társadalmi csoport amellett, hogy anyagi értelemben szegény, az élet más területein (munka, oktatás) is számtalan lehetőségtől meg van fosztva, választási lehetőségeik számtalan szempontból erősen korlátozottak. Területi szegregációról beszélünk, amikor a kirekesztés térben is megnyilvánul - azaz a különböző etnikai csoportok, társadalmi rétegek lakóhelye erőteljesen elkülönül például egy településen belül (Mező 2013). Integráción, antiszegregáción pedig e helyzetek felszámolását, az érintettek választási lehetőségeinek bővítését értjük, Amartya Sen-i értelemben (Sen 2003).

6 Munkánk e szakaszának módszertanáról, eredményeiről több helyen is beszámoltunk (Málovics, Mihók, Szentistványi, Balázs 2011; Málovics, Mihók, Szentistványi, Balázs, Pataki 2012), így itt most e szakaszra csak nagyon röviden térünk ki.

7 E fázis módszertanáról és eredményeiről részletesen beszámol Szentistványi, Málovics, Mihók (2012).

8 Ezt a helyi sajtóban megjelenő cikkek is mutatják: http://szegedma.hu/cimke/cigany.

9 Részvételi akciókutató csapatunknak tagja egy önkormányzati képviselő, aki a helyi önkormányzati munka során igyekszik hangot adni a társadalmi integráció ügyének.

10 Politikai eliten jelen esetben a helyi önkormányzatok többségét még mindig domináló „nagy pártokat”, a FIDESZ-t és az MSZP-t (és szövetségesi köreiket) értjük. Ők azok, akik az elmúlt évtizedben, évtizedekben hatalmi helyzetben voltak a helyi önkormányzatokban, így megfigyeléseink is rájuk vonatkoznak.

11 Ezzel nem szeretnénk azt sugallni, hogy jelenleg az a probléma Magyarországon, hogy a társadalomkutatók „rossz tanácsokkal” látják el a társadalmi döntéshozókat - sőt, mi személyesen inkább azt tapasztaljuk, hogy a tudományos eredmények egyáltalán nem vagy alig épülnek be a szakpolitikai döntéshozatalba. Sajnos egyelőre igen gyengének tűnik hazánkban a „science-policy interface"-nek nevezett párbeszéd, ami természetesen nem csak a szakpolitikusok hibája.

12 Az, hogy egy szegregátumban milyen módszertani kihívásokkal találja magát szembe egy jellemzően középosztálybeli közeghez szokott kutató, amikor pl. egy szigorúan moderált fókuszcsoportot vagy egy módszertanilag tökéletes kép-hang folyamatot szeretne megszervezni, külön tanulmány tárgyát képezhetné. A részvételi akciókutatás nagy rugalmasságot követel meg a társadalomkutatóktól (Málovics, Mihók, Szentistványi, Balázs 2011; Smith, Brazini, Chambers, Jansen, Romero; Smith, Romero 2010), a konvencionális, standardizált módszertanok precíz alkalmazásáról sokszor le kell mondani: az ezekhez való merev ragaszkodás könnyen kudarchoz vezethet, mert ezek követelményrendszere teljesen eltér az érintettek normarendszerétől.

\section{Irodalom}

Babbie, E. (2008): A társadalomtudományi kutatás gyakorlata. Balassi Kiadó, Budapest Bodorkós B. (2010): Társadalmi részvétel a fenntartható vidékfejlesztésben: a részvételi akciókutatás lehetö- 
ségei. Doktori értekezés, Szent István Egyetem, Környezettudományi Doktori Iskola, Gödöllő. http://szie.hu//file/tti/archivum/Bodorkos_B_ertekezes.pdf. (Letöltés: 2011. május 28.)

Bradbury, H., Reason, P. (2003): Action research. An opportunity for revitalizing research purpose and practices. Qualitative Social Work, 2., 155-175.

Catalani, C., Minkler, M. (2010): Photovoice: A review of the literature in health and public health. Health \& Education Behaviour, 3., 424-451.

Chung, K., Lounsbury, D. W. (2006): The role of power, process, and relationships in participatory research for statewide HIV/AIDS programming. Social Science \& Medicine, 8., 2129-2140.

Coleman, J. S. (1994): Társadalmi tőke. In Lengyel Gy., Szántó Z. (szerk.): A gazdasági élet szociológiája. Aula Kiadó, Budapest, 99-127.

Fábián Z., Sik E. (2006): Előitéletesség és tekintélyelvüség. Tárki, Századvég, Budapest http://www.tarki.hu/adatbank-h/kutjel/pdf/a895.pdf (Letöltés: 2014. május 23.)

Farkas Zs. (2008): Egy tradicionális cigányközösség integrációs törekvései. Doktori disszertáció. ELTE Társadalomtudományi Kar, Szociológia Doktori Iskola, Budapest

Farkas Zs. (2012): Hidak és sorompók. A telepfelszámolásban, a településeken végzett terepmunka tapasztalatai és integrációs hatásai. Társadalmi Együttélés, 4., 1-21.

Ferge Zs. (2003): Kétsebességủ Magyarország. ELTE TáTK Szociális Munka és Szociálpolitika Tanszék, Budapest

Forray R. K., Mohácsi E. (2002): Esélyek és korlátok. A magyarországi cigány közösség az ezredfordulón. Gypsy Studies - Cigány Tanulmányok, Pécsi Tudományegyetem, Bölcsészettudományi Kar, Neveléstudományi Intézet, Romológia és Nevelésszociológia Tanszék, Pécs

FRA (2010): A romák és travellerek lakáskörülményei az Európai Unióban Összehasonlitó jelentés. Az Európai Közösségek Hivatalos Kiadványainak Hivatala, Luxemburg

Harvey, D. (1973): Social justice and the city. Johns Hopkins University Press, Baltimore

Jelinek Cs., Bodnár J., Czirfusz M., Gyimesi Z. (szerk.) (2013): Kritikai városkutatás. L’Harmattan, Budapest

KIM Társadalmi Felzárkózásért Felelős Államtitkárság (2011): Nemzeti Társadalmi Felzárkóztatási Stratégia - Mélyszegénység, gyermekszegényeség, romák - (2011-2020). Közigazgatási és Igazságügyi Minisztérium Társadalmi Felzárkózásért Felelős Államtitkárság, Budapest, http://romagov.kormany.hu/download/8/e3/20000/Strat\%C3\%A9gia.pdf. (Letöltés: 2012. május 6.)

Kindon, S., Pain, R., Kesby, M. (2007): Participatory action research. In: Kindon, S., Pain, R., Kesby, M. (eds.): Participatory action research approaches and methods. Connecting people, participation and place. Routledge, New York

Ladányi J., Szelényi I. (2004): A kirekesztettség változó formái. Közép-és délkelet-európai romák történeti és összehasonlitó szociológiai vizsgálata. Napvilág Kiadó, Budapest

Lefebvre, H. (1993): The production of space. Blackwell, Cambridge

Levin, M. (2012): Academic integrity in action research. Action Research, 2., 133-149.

Málovics Gy., Mihók B., Szentistványi I., Balázs B. (2011): Kirekesztett társadalmi csoportok és helyi emberi jogok: egy szegedi részvételi akciókutatás előzetes tanulságai. In. Pataki Gy., Vári A. (szerk.): Részvétel - akció - kutatás. Magyarországi tapasztalatok a részvételi-, akció- és kooperatív kutatásokból. MTA Szociológiai Kutatóintézet, Budapest, 84-119.

Málovics Gy., Mihók B., Szentistványi I., Balázs B., Pataki Gy. (2012): Participatory action research for local human rights: The case of Roma minority in Szeged, South-Hungary. In. Renn, O., Reichel, A.; Bauer, J. (eds.): Civil society for sustainability - A guidebook for connecting science and society. Europäischer Hochschulverlag, Bremen, 149-170.

Mani, A., Mullainathan, S., Shafir, E., Zhao, J. (2013): Poverty impedes cognitive function, Science, 341., 976-980.

Mezö B. (2013): Településszerkezet, területhasználat és a roma szegregációs folyamatok kapcsolata Hajdúböszörményben. Doktori értekezés. Debreceni Egyetem, Kerpely Kálmán Növénytermesztési, Kertészeti és Regionális Tudományok Doktori Iskola

Mihók B., Roboz Á., Nyakas Sz., Szentistványi I., Málovics Gy. (2012): „Kik vagyunk, és hogyan szeretnénk élni?" Üzenet a szegedi cigány szegregátumokból. Részvételi akciókutatással a társadalom peremére szorult szegedi cigány közösségekért.

https://www.essrg.hu/sites/default/files/kiadvany_PAR_Roma_Szeged.pdf.(Letöltés: 2013.február 22.)

Móricz Á. (2012): A térbeli igazságosság nyomában. Tér és Társadalom, 2., 108-114. 
Pataki Gy., Vári A. (szerk.) (2011): Részvétel - akció - kutatás. Magyarországi tapasztalatok a részvételi-, akció-és kooperatív kutatásokból. MTA Szociológiai Kutatóintézete, Budapest

Rátkai Á. (1997) Szeged cigánysága és a Szegedi Cigányprogram. A szegedi cigányság történetéről. Regio - Kisebbség, politika, társadalom, 3-4., 81-109.

Reason, P., Bradbury, H. (2001): Handbook of action research. Sage, Thousand Oaks

Rorke, B. (2011): Beyond rhetoric: Roma integration roadmap for 2020. Priorities for an EU framework for national Roma integration strategies. Open Society Institute, Budapest

Sachs, W. (2003): Environment and human rights. Wuppertal Papers, 137.

Sen, A. (2003): A fejlődés mint szabadság. Európa, Budapest

Smith, L., Brazini, L., Chambers, D-A., Jansen, R.V., Romero, L. (2010): Between idealism and reality: Meeting the challenges of participatory action research. Action Research, 4., 407-425.

Smith, L., Romero, L. (2010): Psychological interventions in the context of poverty: Participatory action research as practice. American Journal of Orthopsychiatry, 1., 12-25.

Szentistványi I., Málovics Gy., Mihók B. (2012): Velük - értük: Részvételi akciókutatás egy roma tanoda kialakításáért. Módszertani Közlemények, 3., 40-50.

Tousek L. (2011): Purification of space: Spatial segregation of Roma in the Czech Republic. http://www.academia.edu/428790/Purification_of_Space_Spatial_Segregation_of_the_Roma_in_the_Czech_Republic. (Letöltés: 2013. szeptember 23.) 


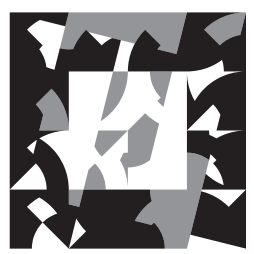

TÉR ÉS TÁRSADALOM | SPACE AND SOCIETY 